\title{
FACTORS WHICH INFLUENCE THE PROCESS OF EXPERIENCING CARDIAC REVASCULARIZATION
}

\author{
Gabriela Marcellino de Melo Lanzoni ${ }^{1}$, Giovana Dorneles Callegaro Higashi², Cíntia Koerich ${ }^{3}$, Alacoque \\ Lorenzini Erdmann ${ }^{4}$, Maria Aparecida Baggio
}

\begin{abstract}
${ }^{1}$ Ph.D. in Nursing. RN of the Secretaria Estadual de Saúde de Santa Catarina (SES/SC). Florianópolis, Santa Catarina, Brazil. E-mail: gabimc@gmail.com

${ }^{2}$ M.Sc. in Nursing. Doctoral student on the Postgraduate Program in Nursing at the Universidade Federal de Santa Catarina (PEN/UFSC). Florianópolis, Santa Catarina, Brazil. E-mail: gio.enfermagem@gmail.com.

${ }^{3}$ RN, SES/SC. Master student, PEN/UFSC. Florianópolis, Santa Catarina, Brazil. E-mail: cintia.koerich@ig.com.br

${ }^{4}$ Ph.D. in Philosophy of Nursing. Full professor of the Department of Nursing and of the PEN/UFSC. Researcher of the National Council for Scientific and Technological Development (CNPq). Florianópolis, Santa Catarina, Brazil. E-mail: alacoque@newsite.com.br ${ }^{5}$ Ph.D. in Nursing. Professor of the Postgraduate Course in Health Sciences, Faculdade Assis Gurgacz . Cascavel, Paraná, Brazil. E-mail: mariabaggio@yahoo.com.br
\end{abstract}

\begin{abstract}
This study aimed to understand the factors which influence the process of experiencing cardiac revascularization surgery for patients, family members and health professionals, in a hospital which is a center of excellence, located in the South region of Brazil. The methodological framework was Grounded Theory. Data collection was undertaken in October 2010 - May 2012 through semi-structured interviews with 33 participants (patients, family members, doctors, nurses, a physical education trainer and a nursing technician), distributed in four sample groups. The personal and institutional intervenient factors identified were: the wait for the surgery, fear of death, use of drains and the orotracheal tube in the post-operative period, pain management, access to the medication, religiosity, the presence of scars, and support from the family and the health professionals. Knowledge of these factors by nurses can guide and benefit the professionals' clinical practice and the care for the revascularized patient in the pre- and post-operative period. DESCRIPTORS: Nursing. Myocardial revascularization. Nursing care.
\end{abstract}

\section{FATORES QUE INFLUENCIAM O PROCESSO DE VIVER A REVASCULARIZAÇÃO CARDÍACA}

\begin{abstract}
RESUMO: Este estudo objetivou compreender os fatores que influenciam o processo de viver a cirurgia de revascularização cardíaca para pacientes, familiares e profissionais de saúde, em um hospital de referência, localizado na região Sul do Brasil. A Teoria Fundamentada nos Dados foi o referencial metodológico. A coleta de dados foi realizada por meio de entrevista semiestruturada, com 33 participantes (pacientes, familiares, médicos, enfermeiros, educador físico, técnico em enfermagem), distribuídos em quatro grupos amostrais, de outubro de 2010 a maio de 2012. Os fatores intervenientes identificados, de ordem pessoal e institucional, foram: espera pela cirurgia, medo da morte, uso de drenos e tubo orotraqueal no pós-operatório, manejo da dor, acesso à medicação, religiosidade, presença de cicatrizes, apoio da família e dos profissionais da saúde. O conhecimento desses fatores por enfermeiros pode orientar e favorecer a prática clínica do profissional e o cuidado do paciente revascularizado no pré e pós-operatório.
\end{abstract}

DESCRITORES: Enfermagem. Revascularização miocárdica. Cuidados de enfermagem.

\section{FACTORES QUE INFLUYEN EN EL PROCESO DE VIVIR LA REVASCULARIZACIÓN MIOCÁRDICA}

RESUMEN: La finalidad del estudio: comprender los factores que influyen en el proceso de revascularización cardiaca para pacientes, familiares y profesionales de la salud, en un hospital de la región sur de Brasil. Como referente metodológico se empleó la Teoría Fundamentada. La recolección de datos se realizó entre octubre de 2010 a mayo de 2012, a través de entrevistas semiestructuradas con 33 participantes (pacientes, familiares, médicos, enfermeras, educadores físicos, técnicos de enfermería), divididos en cuatro grupos. Los factores de orden personal e institucional identificados son: espera para la cirugía, miedo a la muerte, el uso de drenajes y tubo endotraqueal en el postoperatorio, tratamiento del dolor, acceso a la medicación, religiosidad, presencia de cicatrices, apoyo familiar y de los profesionales de la salud. El conocimiento de estos factores por los enfermeros puede orientar y fomentar la práctica clínica profesional y el cuidado de los pacientes revascularizados en el pre y postoperatorio.

DESCRIPTORES: Enfermería. Revascularización miocárdica. Atención de enfermeira. 


\section{INTRODUCTION}

Historically, the cardiovascular diseases have been a priority on the health agenda. In 2008, they were responsible for $30 \%$ of all deaths worldwide. It is calculated that this group of diseases was the primary cause of death in all developing countries until 2010. ${ }^{1}$ Corroborating the projections for the period indicated, in Brazil, diseases of the circulatory apparatus occupied second place regarding deaths in adults, being outnumbered only by deaths from cancer. ${ }^{2}$

In the state of Santa Catarina, in 2011, the number of hospitalizations caused by diseases of the circulatory apparatus increased by $3.18 \%$ compared to 2008 . This data represents $12.17 \%$ of the total of hospitalizations in the state. ${ }^{3}$ It also indicates the financial burden which the cardiovascular diseases represent for the Unified Health System (SUS) and supports the need for the development of strategic interventions in health, which need to be effective in order to reduce the rates of cardiovascular diseases in Brazil. ${ }^{4}$

The $7.4 \%$ growth of the population aged 65 years old or more reflects a change of the national age structure, with a broadening of the whole of the population pyramid. ${ }^{5}$ As a result, the increase of the participation of the adult and older adult population in society requires the medical sciences to produce technological and technical advances, such as surgical techniques. Among the surgical techniques, emphasis is placed on myocardial revascularization, which can prolong life by a mean of 6.5 years, as well as afford an effective improvement in the quality of life of elderly patients. ${ }^{6}$ This has also allowed greater survival for people with chronic and acute diseases, with a reduction in morbidity and mortality related to the circulatory apparatus.

The patients who receive myocardial revascularization may experience changes in their emotional and physical condition resulting from the various elements involved in the complex healthillness process. In the pre-operative period, for example, the patients may show a high prevalence of anxiety. ${ }^{7}$ In the first year following surgery, fear and depression may be present, mainly related to socio-economic aspects. ${ }^{8}$

A recent study with revascularized patients indicates that those who are physically active in the post-operative period present better functional capacity. ${ }^{9}$ Physical activity and a hypocaloric diet are classic examples of elements which can lead to the reduction and to the control of cardiovascular diseases, as well as to the avoidance of relapses. ${ }^{10}$
Nevertheless, the question is asked: why do people who receive cardiac revascularization have difficulty in becoming and remaining active through practising exercise, as well as adopting a healthy diet? What are the difficulties for overcoming hospitalization and the fear of the surgery? What promotes or hinders the patient's recovery after being discharged from hospital?

It is understood that the answers to these questions do not have a linear relationship of cause and effect, in particular in the context of a society of such complex phenomena, ${ }^{11}$ which involve the health sector. This being the case, it is relevant to investigate the elements which influence this process, from diagnosis and surgical treatment of the coronary insufficiency through to the subject's adaptation to the new health condition, who needs appropriate therapeutic support and constant encouragement to maintain a healthy lifestyle. Thus, a further question emerges: what are the factors which influence the process of living of patients who underwent the surgical experience of revascularization of the myocardium? Consequently, this study's objective was to understand the factors which influence the process of experiencing myocardial revascularization surgery for patients, family members and health professionals, in a hospital specializing in cardiac surgery, located in the South region of Brazil.

\section{METHODOLOGY}

This is an excerpt from a research project titled "Giving meaning to the surgical experience and the process of living of the patient who underwent myocardial revascularization surgery". The project was approved by the Committee for Ethics in Research involving Human Beings of the institution where the study was undertaken, under n. $001 / 2010$. The study is qualitative, exploratory and descriptive, undertaken based on a rereading of data deriving from the Intervenient component, inherent to the paradigmatic model of Grounded Theory (GT), which was the methodological framework. GT explores the meaning of the phenomena and allows interrelation between the data, as well as constant comparative analysis. ${ }^{12}$

The scenario studied was a health institution - a center of excellence in cardiac surgery - located in the South region of Brazil, in the period October 2010 - May 2012. The selection of participants was intentional. The 'snowball' technique was used for composing the sample. The inclusion criteria to participate in the research were: a) patients: to be an adult, to have undergone myocardial revascu- 
larization surgery in the period 2005 - 2010 and be monitored by the Cardiac Rehabilitation Service (CRS) of the institution selected for the study; b) family members: to be an adult and the main carer of the patient during the period of hospitalization and following discharge from hospital; c) health professionals: to have worked in the institution for a minimum of one year and to have contact with revascularized patients.

The invitation to the patients and health professionals to participate in the research took place in the context of the institution studied. The study's objective and methodology were explained during the first meeting with the participant. Once the participant accepted to participate in the research, a meeting was scheduled for undertaking the interview, consent being given through signing the Terms of Free and Informed Consent.

For access to the family members, the patients interviewed made the first contact with the respective family member in order to consult him or her regarding interest in participating in the research. These informed the researchers of a date and time for the meeting, which was aimed to formalize the invitation and present the research's aim and methodology to the family member. All the family members consented to participate in the study and to hold the interview during the first meeting/contact with the researchers.

For making up the first sample group (of patients), the health professionals working in the CRS indicated those who had undergone myocardial revascularization. Thus, the process of collecting and analyzing data was begun. The data were collected through individual, semi-structured interviews, in which the initial question was: "Tell me about the factors which influenced your experience of having undergone myocardial revascularization surgery". The direction of the subsequent questions was guided by the researchers based on the interviewees' answers. During the process of data collection and analysis, it became necessary to include a further three sample groups, due to the generation of questions and hypotheses.

Table 1 shows the sample groups, the number of participants in each sample group, where the data were collected, and the hypotheses produced for each sample group, which indicated the formation of the following sample groups.

Data saturation was achieved when there was repetition of the information and absence of new elements for the consolidation of the categories found. Data collection was finalized with 33 participants. The validation of the theoretical model per se was effected with the last sample group, by a patient who had not been interviewed prior to that point, who had undergone myocardial revascularization surgery in the institution, and by two nurse researchers, who were experts in the method. It should be noted that the interviews were recorded digitally and transcribed in full. Analysis of the data occurred simultaneously with the collection and followed the stages proposed by GT: open, axial and selective codification.

Table 1 - Sample groups, participants, place of data collection and hypotheses

\begin{tabular}{|c|c|c|c|}
\hline $\begin{array}{l}\text { Sample } \\
\text { groups }\end{array}$ & Participants & Place of collection & Examples of hypotheses/questions \\
\hline 1 & 8 patients & $\begin{array}{l}\text { Cardiac Rehab. } \\
\text { Services (CRS) }\end{array}$ & $\begin{array}{l}\text { - The discovery of the disease and the hospitalization cre- } \\
\text { ate fear and the post-operative period is very difficult. } \\
\text { How does the professional influence this process? } \\
\text { - Scars influence satisfaction with self-image, principally } \\
\text { among women. What influence do their partners and } \\
\text { carers have in this regard? }\end{array}$ \\
\hline \multirow{4}{*}{2} & 2 nurses & $\begin{array}{c}\text { Coronary Care } \\
\text { Unit (CCU) }\end{array}$ & \multirow{4}{*}{$\begin{array}{l}\text { - The professionals provide guidance to the patient and } \\
\text { the family member both in the pre- and post-operative } \\
\text { period. Furthermore, they perceive the presence of the } \\
\text { family member in the care as fundamental. How does } \\
\text { the family member contribute in the care for the patient? }\end{array}$} \\
\hline & 2 doctors & $\begin{array}{c}\text { Outpatient Dept/ } \\
\text { CCU }\end{array}$ & \\
\hline & 1 physical education trainer & CRS & \\
\hline & 1 nursing technician & CRS & \\
\hline 3 & $\begin{array}{l}4 \text { patients and } \\
5 \text { family members }\end{array}$ & Home & $\begin{array}{l}\text { - Family members provide support for the patient, how- } \\
\text { ever, they observe their attitudes and reveal data which } \\
\text { had not been mentioned. Have the patients being talk- } \\
\text { ing about the ideal, or about what actually happened? }\end{array}$ \\
\hline 4 & 10 patients & CRS & - Theoretical saturation achieved. \\
\hline
\end{tabular}


In open codification, the data were analyzed line by line with the aim of identifying each incident and naming them with preliminary codes. Following that, the same were reunited through the similarities and differences based on the elaboration of the conceptual codes.

In the axial codification, the data were regrouped for relating the subcategories to their categories, so as to obtain a clearer and more complete explanation regarding the phenomenon, as well as its properties and dimensions.

In the selective codification, the subcategories in categories found were contrasted and analyzed continuously, with the objective of integrating them and of redefining them, so as to identify the central category. In order to organize and present the data, the paradigmatic model was used, made up of six components, namely: context, causal conditions, intervenient conditions, strategies, consequences and phenomenon. ${ }^{12}$

Two categories of analysis emerged (Contrasting feelings experienced during the hospitalization; and, Revealing the perception of the post-operative period) which make up the phenomenon's intervenient conditions: 'Perceiving the process of experiencing the myocardial revascularization surgery as susceptible to influences created by the patient's own anxieties, by the emotional support of family members, and by the therapeutic and relational support of the health professionals'. Given this component's relevance and richness of information, it was decided to present them separately.

Ethical aspects were respected at all stages of the research. ${ }^{13}$ In order to preserve the confidentiality of information, the sample groups were identified by a letter followed by an ordinal number corresponding to each participant (' $E$ ' for the first sample group, ' $\mathrm{P}$ ' for the second, ' $\mathrm{F}$ ' for the third and ' $G$ ' for the fourth).

\section{RESULTS}

The analysis of the data resulted in two categories, termed "Contrasting feelings experienced during the hospitalization" and "Revealing the perception of the post-operative period".

\section{Contrasting feelings experienced during the hospitalization}

This category is related to the phenomenon, to the extent that it allows greater comprehension of the first stage of the process of living through myocardial revascularization, that is, from the discovery of the heart disease through to the undertaking of the surgery, made up of two subcategories.

In the first subcategory, titled 'Emphasizing the positive experiences during the hospitalization', the patients emphasized, as a positive experience, the fact that they managed to keep themselves calm in order to cope with the fear after learning of the need for surgical treatment. They emphasize the quality of the attendance from the health team, based in the professional's competence, as well as in the good interpersonal relationship, promoted by embracement and moments of relaxation. This may be observed in the accounts: I am a calm person, but brave. I was not at all scared when the doctor said that I would be operated on (E4); We were very well treated, they always joked with us; they gave a lot of support, a lot of tenderness. Thus, I don't know how, they raise your spirits more [...] (E3).

Spirituality was also given significance as important in the experience of going through surgery, as the patients were able to share their distress with God, and have, in faith, the hope for the achievement of good results following the operation, as shown by the statement: my wife prayed a lot and this gave me a lot of strength [...] (G6).

In the second subcategory, titled 'Revealing the difficulties experienced during the hospitalization', the fear of death and of anesthesia, knowledge of the operation's risks and being away from one's family acted as a barrier, hindering the acceptance of the operation by the patients. Some, seeking to accept the operation, even though this was a difficult decision, passed through moments of sadness and despair, as the account below describes: oh, it was terrible! I felt deep despair. I had never had an operation, I had never even had stitches [...]. It was very sad, I couldn't accept the situation [...] (E2).

Patients and family members alike mention the uncomfortable facilities for the patient's companion to rest in and the restrictive diet (relatively tasteless, and served cold) as conditions which added to the difficulties experienced during the inpatient treatment. In addition to this, the excessive wait between the diagnosis and indication for surgery and the surgical procedure are responsible for aggravating the anxiety and worsening the health conditions of some patients, as the following account evidences: because of the wait for the operation, I was getting worse and worse, and the pain [thoracic] was crushing me more and more [...] and on the last night [before the operation], I had to take three tablets [analgesics] (E1). 
The patients relate the negative experience of the wait for the operation to the period in which they had to wait in the Emergency Room for a bed to become available in the inpatient unit. They had to spend several days on trolleys, in the corridors, without a companion keeping them company. In the same way, in the inpatient unit, they spend various days waiting for the operation, this sometimes being cancelled and rearranged, in most cases. Thus, the period of waiting between being admitted to the hospital and having the operation was between 17 and 60 days. The reason for the delay between the diagnosis and the surgical intervention was explained to the patients by the professionals as being related to the availability of space for hospitalization in the coronary care unit (CCU) and to the availability of the operating room and an anesthetist. As a result, these conditions were connected because of being essential for undertaking the operation, as the following account illustrates: spending 30 days hospitalized in order to do the operation was a source of anxiety and it seemed that the time when I would go [for the operation] would never come.., and they [the professionals] said that there wasn't an anesthetist [...] (E3).

\section{Revealing the perception of the post- operative period}

This category is made up of two subcategories, presenting information complementing the first category. It evidences the impact perceived by the patients following the operation and emphasizes the importance of the hospital and home settings, as well as of the people involved in the process of experiencing the cardiac surgery.

The first subcategory, "Experiencing challenges in the post-operative period", describes that the first hours following the operation, in the CCU, are difficult for the patient due to the presence of the orotracheal tube, the chest drains, and pains in the body. The patients asserted that they felt disoriented in time and space and uncomfortable with the lights which were constantly on and the impossibility of communicating while the orotracheal tube was in place, in addition to the intense pain at the time of extubation and when coughing, which in each episode worsens the pain in the place of the thoracic incision, as the following accounts illustrate: the most difficult part is, you see, as I am telling you, is the recovery. It hurts your chest when you cough [...] (E4); when I see a person who is intubated, I can't express myself [...] because it is terrible! The pain is appalling, the same for the drains [...]. There isn't anywhere it doesn't hurt [...] (E2).
Facing the presence of arrhythmias, as a postoperative complication, causes important anxiety. According to the patients' reports, the greatest fear is in the potential need to receive electrocardioversion. In the accounts, one can identify the patients' lack of knowledge about the procedure: I had arrhythmia, from 80 it would go to 170 [heartbeats at minute] in one go. They were going to give me the shock and it turned out not to be necessary [...]. That was worst of all for me [...]. I was afraid of receiving the shock. I never had it, I don't know how it would have been (E1).

Both in hospital and at home, in accordance with the established interactions, the family members were able to provide emotional and physical support for locomotion, eating and pain control, as the following account states: nowadays, it's him who takes the medication. In the beginning it was me who gave it to him, because he would take it wrong. He didn't pay attention [...], sometimes he was supposed to take one and he thought it was time for the next one [...] (F6).

Although the participants have experienced some challenges indicated above, they also show themselves to be happy for having escaped with their lives from the infarction and from the surgical procedure, as they were scared of becoming bedridden, dependent on other people. The relief of the symptoms caused by the coronary obstruction represented a new perspective of life, as they report: nowadays I am happy! Because considering how I used to be, today I am a new man (E1); [...] now I am always going out dancing on the weekend with my friends [...]; I think I have a very good life (G4).

After having the infarction, suddenly, the patients noticed, in the post-operative period, that their functional performance was below that expected, relative to their lifestyle. They understand, however, that it is necessary to live with the restrictions and feelings in adherence to the rehabilitation phase, such as the restriction on physical effort and the occasional or intermittent pain, as shown in the following account: [...] It is a different lifestyle [...]. I can't use strength, using strength hurts, if the weather is cold it hurts. It hurts! It hurts all day long (F1).

Regarding the practice of physical exercise and adjusting one's diet following discharge, the patients stated that they were making an effort to keep up healthy habits. However, many reported that old habits are difficult to break, such as a beer or a barbecue at weekends, as the following account makes clear: Just thinking that the weekend is coming, that sizzling steak with an ice-cold beer and everything, and a man has to say goodbye to all that? [...] You can, once in a while, can't you? (G9). While some patients 
confirmed that they undertake exercise as part of their routine, others reported being sedentary, stating that they do not like exercising. The increase in weight is the main incentive to practice walking, although they are aware of the other benefits of this practice: I think it's terrible [having to take physical exercise], really. I punish myself every day about this I say to myself: I have to walk, I have to walk, I have to walk [...]. I used to weigh $106 \mathrm{~kg}$, now I weigh $102 \mathrm{~kg}$, I need to get down to $80 \mathrm{~kg}(\mathrm{~F} 5)$.

Another challenge revealed was the scars resulting from the operation, which, in particular for the women, were a source of shame, as large incisions are made both on the sternal region and on the lower limbs. Aiming to disguise these, female patients used clothes which covered their bodies more in these areas, as in the account: [...] my leg looks really ugly, before, I used to wear shorts, now I don't use those anymore [...]. I think it calls attention, people are going to be looking, so, for me, the more reserved my clothes are, the better (F9).

The second subcategory, "Professionals contributing to the cardiac patient's process of living", describes both the health team's participation in the recovery, and their perspective in relation to the efforts made by the patients who receive myocardial revascularization.

In the post-operative period, the multi-professional work enriches the clinical practice and strengthens the patient's recovery/rehabilitation, with emphasis on the support for exercise and healthy eating from the CRS, from the pre-operative period, although its presence is more pronounced after the operation, as the following account illustrates: We show that there is treatment, that there is life after the operation, giving examples of people who have a normal life, often better than they had before [...]. But this doesn't happen overnight, it requires monitoring (P1).

Myocardial revascularization surgery involves many changes and much uncertainty in relation to the future, such as the possible inability to work, having to retire and reduce the family income, among others. Thus, in this scenario, the health professionals perceive the importance of pre- and post-operative advice, in which they can suggest possible paths to take to resolve the problems resulting from the operation, as the accounts below illustrate: when they leave CCU or even when they find out that they were going to be operated on, they ask various questions. I think that we [the professionals] are their rock for the surgery (P3).

From the professionals' point of view, the main problems for the continuity of the treatment, by the patients, following discharge from hospital, are the difficulty in arranging medical consultations, and obtaining medications, when these are not available through the SUS. In line with this, the patients state that they use the outpatient services of the hospital where the operation was undertaken; in particular, for the consultations with cardiologists and for medications, when available. The main purpose is to have health monitoring after discharge from hospital: from work I go to collect the diabetes medication, and the strip for measuring the diabetes too [in the Health Center]. They never have them [...]. I'm monitored by the rehabilitation doctor [...] because the person who does the rehabilitation schedules the tests and can arrange a consultation very easily there (F1).

\section{DISCUSSION}

The myocardial revascularization operation is understood by this study's participants as a complex procedure, offering the risk of death and requiring changes in lifestyle, so as to avoid further events involving coronary obstruction. Although preparation is undertaken with the patients, following the preoperative advice, stress and anxiety are observed, these being common in unfamiliar situations requiring changes in life routines. ${ }^{14}$

In this regard, this study's findings indicate that the patients experience receiving the news of the need to undergo myocardial revascularization surgery with courage, and authorize the surgical treatment, although insecurity and the fear of death are present, conditions which are inherent to the risks involved in major surgery. At this point, emphasis is placed on the conflict experienced by the patient on rationally accepting the inseparability of two contradictory notions. This allows the union of two notions, which tend to be exclusive, seeing them simultaneously as mutually antagonistic and complementary: ${ }^{11}$ the need for, and the risk posed by, the operation.

At all stages, from the pre-operative period through to the moment of discharge from hospital, the various factors can be minimized with assistance from humanitarian nursing, which aims to minimize negative feelings, indicated by the patients, and to transmit security and comfort, which culminate in a good relationship. ${ }^{15}$ Thus, it is ascertained that the professionals' technical competence and scientific knowledge are coherent with the subjectivity of the care which forms the basis for the nursing practice ${ }^{16}$ and is able to influence the experience of the patient indicated for heart surgery, both in the pre- and post-operative stages. 
The relationship between religiosity/spirituality and the cardiovascular diseases is also noteworthy, as it is not only the physical or biological elements which stand out in this process. On the contrary, in view of the complexity of the human being, its multiple facets, when integrated, weave the composition of the whole. ${ }^{11}$ The spiritual dimension is positively associated with the reduction of the prevalence of depression, greater survival and lower blood pressure levels and rates of postoperative complications. ${ }^{17}$ In this regard, special attention must be given by the professionals so as to strengthen this dimension for the revascularized patients.

In relation to the difficulties experienced, the sensation of imminent death provokes fear and terror in the human being, with pain being more violent when the being's uniqueness and the intensity of one's family bonds is recognized. ${ }^{18}$ It is added that "the horror of death is the emotion, the feeling or the awareness of an emptiness, of a nothing, which opens up where once there had been individual fullness, that is, traumatic consciousness". ${ }^{18: 33}$

It thus becomes essential to identify these feelings in cardiac surgery's pre-operative period with a view to increasing the patients' proactive actions, as myocardial revascularization can represent a new reality. This requires effective reorganization, as it involves changes in self-image, insecurity in relation to the future and fear of dependence on other persons and inability to work. ${ }^{19}$

In relation to the hospital environment, the revascularized patients' process of living, the discomfort of sharing privacy with other patients, and dissatisfaction with the food were indicated as elements which had a negative influence, corroborating the findings of another study during the inpatient treatment. ${ }^{20}$

The long wait for the operation, or the postponement of the operations, experienced by this study's participants, in addition to creating greater costs for the hospitals, can increase the risk of clinical complications for the patient. As the postponement of the operation exposes the patients to distress and anxiety, the health professionals must make efforts to avoid these, through undertaking responsible evaluation and guidance in the pre-operative period..$^{21}$

In this regard, the SUS has sought management models which privilege practices of humanization, with a view to promoting greater service user satisfaction and patient safety. This last dimension was considered the most valued in the hospital attendance by a group of service users who received cardiac surgery, who evaluated the quality of the SUS.22

In relation to the post-operative period, cardiac patients receiving inpatient treatment in an intensive care unit, in another study scenario, corroborate that the period of hospitalization was difficult due to the discomforts caused by the environment, such as: lights left on, noisy equipment in activity, and constant handling of the patients, as well as being away from the family. ${ }^{15}$ The incisions, the drains and the orotracheal tube also caused discomfort during the recovery process. Besides the discomfort, the presence of drains and tubes significantly impairs communication during the patient's stay in the intensive care unit. ${ }^{23}$

The control of post-operative pain is an important element in the reduction of complications and suffering. Generally, the diagnosis of Acute Pain is identified in patients in the post-operative period following cardiac surgery; the places particularly indicated are: the sternal region (the place of the surgical incision) and anterior thorax (where the chest drains are placed). ${ }^{24}$ Pain is commonly present in the first to the third days after the operation, principally in older adults. ${ }^{25}$ Pain is a sensory, subjective and individual experience. The nurse is considered a member of the multiprofessional team, which constantly monitors the patient during inpatient treatment. She undertakes care plans directed at pain management, and this professional must be attent to the development of care strategies, individualized for each patient.

The family is perceived as an important source of support for the patient, principally in the post-operative period. The family has been indicated as a support network used by persons in situations of illness and inpatient treatment, as family relationships are important strategies for overcoming the challenges of this process. ${ }^{26}$

Concerning the return to work activities, although the study found patients who were satisfied with their health conditions, it is observed that dissatisfaction relating to work is common, it being the case that this results in low self-esteem and financial dependence. ${ }^{27}$ In relation to the undertaking of physical activity and the adaptation to the new diet, on the other hand, it has been evidenced in other studies that these elements, considered fundamental for the control of cardiovascular diseases, ${ }^{10}$ continue to be absent from the routine of some patients who receive cardiac surgery..$^{19}$ Thus, introducing these healthy practices, or turning them into a habit, is characterized as a challenge in the post-operative period. 
Another significant element emphasized by the participants - mainly by the revascularized women - was the scars. The women feel ashamed of showing their body, marked by a scar, and perceive, as a problem, difficulty in accepting the scars on their chest and on their legs. Women's concern with how their spouses regard the scars is considered common and normal, whereas the men present their scars as an act of heroism..$^{28}$

The professional work in the CRS is a therapeutic resource for secondary prevention of ischemic cardiopathy, which, after the revascularization of the myocardium, can bring positive results for a better quality of life. Cardiac rehabilitation can encompass other dimensions of healthy living, apart from physical training. ${ }^{29}$ In this regard, the articulation between the CRS and the other services offered in the outpatient service (which includes medical consultations by specialists and the provision of medications) promotes the continuity of the health actions, with a view to comprehensive care for the service user.

The guarantee of the right to health, guided by principles of universality, equality and comprehensiveness, has existed for 20 years in Brazil, with repercussions, including in the drug therapy. Thus, the pharmaceutical assistance through the Brazilian legal system was able to attend the increase in lawsuits, to put this right into effect. Therefore, part of the Brazilian population is not passively accepting the absence of drugs in the local health centers and/or health clinics. ${ }^{30}$ However, access to the information and to the justice system, free of charge, are requirements for the achieving of full exercising of one's rights as a user of the SUS.

\section{FINAL CONSIDERATIONS}

During inpatient treatment and after discharge, the revascularized being experiences personal and institutional challenges. The patient needs to overcome the fear of surgery and of death, the wait for the operation, the management of the pain, the presence of drains and the orotracheal tube in the post-operative period, the access to medication and the scars, as well as to count on support from religiosity and the presence of the family and of the health professionals.

The present study's data reveal meanings which alter/influence the process of experiencing cardiac revascularization, which provide a theoretical basis for the nursing care for this patient in particular. Although this research's results reflect the experience of revascularized patients from a public hospital and, therefore, cannot be generalized to other hospital institutions, various factors influence the process of living of the patient who received myocardial revascularization. Being aware of these factors can contribute to a more responsible clinical practice and awaken the nurses to a basic activity: effective pre- and post-operative guidance.

Nurses have a fundamental role in the care for the revascularized being, due to their greater proximity, full-time, during the period of inpatient treatment. This is a relevant opportunity for building ties with the patient. To this end, the significant possibility is evidenced of identifying the intervenient elements of the process of experiencing the myocardial revascularization surgery, so as to promote changes and improvements in the patient's therapeutic trajectory and recovery, and in the maintenance of the patient's health.

\section{REFERENCES}

1. World Health Organization. Cause-specific mortality [online]. World Health Organization; 2008 [acesso 2013 Ago 10]. Disponível em: http:/ / apps. who.int/ghodata/?vid=10012\#

2. Ministério da Saúde (BR). DATASUS. Morbidade Hospitalar do SUS por local de internação - Brasil [online]. Ministério da Saúde; 2010 [acesso 2013 Ago 10]. Disponível em: http://tabnet.datasus.gov.br/ cgi/tabcgi.exe?sih/cnv/niuf.def

3. Ministério da Saúde (BR). DATASUS. Sistema de informações hospitalares. Internações segundo capítulo CID-10 [online]. 2012 [acesso 2013 Ago 10]. Disponível em: http:/ / tabnet.datasus.gov.br/cgi/ tabcgi.exe?sih/cnv/nisc.def

4. Gallani MCBJ, Cornelio ME, Agondi RF, Rodrigues RCM. Conceptual framework for research and clinical practice concerning cardiovascular healthrelated behaviors. Rev Latino-Am Enferm. 2013; 21(spe):207-15.

5. Ministério do Planejamento, Orçamento e Gestão (BR). Instituto Brasileiro de Geografia e Estatística - IBGE. Sinopse do Censo Demográfico [online]. 2010. Rio de Janeiro; 2011. [acesso 2013 Ago 10]. Disponível em: http://www.ibge.gov.br/home/ estatistica/populacao/censo2010/sinopse.pdf

6. Pivatto-Júnior F, Valle FH, Pereira EMC, Aguiar FM, Henn NT, Behr PEB, et al. Long-term survival of octogenarian patients submitted to isolated coronary artery bypass graft surgery. Rev Bras Cir Cardiovasc. 2011; 26(1):21-6.

7. Carneiro AF, Mathias LAST, Rassi-Júnior A, Morais NS, Gozzani JL, Miranda AP. Avaliação da ansiedade e depressão no período pré-operatório em pacientes submetidos a procedimentos cardíacos invasivos. Rev Bras Anestesiol. 2009; 59(4):431-38. 
8. Lima FET, Magalhães FJ, Silva DA, Barbosa IV, Melo EM, Araujo TL. Emotional alterations gifts in the patients who underwent coronary artery bypass. Rev Enferm UFPE. 2010; 4(2):785-91.

9. Nery RM, Martini MR, Vidor CR, Mahmud MI, Zanini M, Loureiro A, et al. Changes in functional capacity of patients two years after coronary artery bypass grafting surgery. Rev Bras Cir Cardiovasc. 2010; 25(2):214-22.

10. Corrêa ICF, Costa JDA, Ferreira PAM, Ferreira FMM. Atividade física e efeitos sobre os fatores de risco da doença cardiovascular em indivíduos revascularizados do miocárdio. Rev Pesq Saude. 2010; 11(1):18-22.

11. Morin E. A cabeça bem-feita: repensar a reforma, reformar o pensamento. 15a ed. Rio de Janeiro (RJ): Bertrand Brasil; 2008.

12. Strauss AL, Corbin J. Pesquisa qualitativa: técnicas e procedimentos para o desenvolvimento de teoria fundamentada. 2 ed. Porto Alegre (RS): Artimed; 2008.

13. Ministério da Saúde (BR). Conselho Nacional de Saúde, Comissão Nacional de Ética em Pesquisa. Resolução n. 196 de 10 de outubro de 1996: diretrizes e normas regulamentadoras de pesquisa envolvendo seres humanos. Brasília (DF): MS; 1996.

14. Broddadottir H, Jensen L, Norris C, Graham M. Health-related quality of life in women with coronary artery disease. Eur J Cardiovasc Nurs. 2009; 8(1):18-25.

15. Parcianello MK, Fonseca GGP, Zamberlan C. Necessidades vivenciadas pelos pacientes póscirurgia cardíaca: percepções da enfermagem. Rev Enferm Cent-Oeste Min. 2011; 1(3):305-12.

16. Baggio MA, Callegaro GD, Erdmann AL. Compreendendo as dimensões de cuidado em uma unidade de emergência hospitalar. Rev Bras Enferm. 2008; 61(5):552-7.

17. Lucchetti G, Lucchetti ALG, Avezum Junior A. Religiosity, spirituality and cardiovascular disease. Rev Bras Cardiol. 2011; 24(1):55-7.

18. Morin E. O homem e a morte. Rio de Janeiro (RJ): Imago; 1997.

19. Nobre TTX, Reis LA, Torres AG, Alchieri JC. Aspectos da personalidade e sua influência na percepção da dor aguda em pacientes submetidos à cirurgia cardíaca. J Bras Psiquiatr. 2011; 60(2):86-90.
20. Oliveira SG, Quintana AM, Budó MLD, Kruse MHL, Beuter M. Internação domiciliar e internação hospitalar: semelhanças e diferenças no olhar do cuidador familiar. Texto Contexto Enferm. 2012; 21(3):591-9.

21. Sá C, Carmo SPG, Canale TSL. Avaliando o indicador de desempenho suspensão cirúrgica, como fator de qualidade na assistência ao paciente cirúrgico. Enferm Glob. 2011; 10(23):190-9.

22. Borges JBC, Carvalho SMR, Silva MAM. Quality of service provided to heart surgery patients of the Unified Health System-SUS. Rev Bras Cir Cardiovasc. 2010; 25(2):172-82.

23. Werlang SC, Azzolin K, Moraes MA, Souza EN. Comunicação não verbal do paciente submetido à cirurgia cardíaca: do acordar da anestesia à extubação. Rev Gaúch Enferm. 2008; 29(4):551-6.

24. Pivoto FL, Lunardi Filho WD, Santos SSC, Almeida MA, Silveira RS. Diagnósticos de enfermagem em pacientes no período pós-operatório de cirurgias cardíacas. Acta Paul Enferm. 2010; 23(5):665-70.

25. Xavier TT, Torres GV, Reis LA, Silva RAR, Costa IKF, Mendes FRP. Post-surgical health and pain assessment for elderly submitted to cardiac surgery. Texto Contexto Enferm. 2011; 20(spe):232-37.

26. Montefusco SA, Bachion MM. Impaired housekeeping: nursing diagnosis in relatives of hospitalized patients with chronic ailments. Rev Eletron Enferm. 2011; 13(2):182-9.

27. Dantas RAS, Rossi LA, Costa MCS, Vila VSC. Qualidade de vida após revascularização do miocárdio: avaliação segundo duas perspectivas metodológicas. Acta Paul Enferm. 2010; 23(2):163-8.

28. Silva PFC, Caldas CP. Implicações psicossociais do envelhecimento: o caso da cirurgia de revascularização do miocárdio em mulheres idosas. Rev Kairós. 2007; 10(2):189-204.

29. Pinheiro DGM, Pinheiro CHJ, Marinho MJF. Estilo de vida e importância da educação em saúde na reabilitação cardíaca após cirurgia de revascularização do miocárdio. Rev Bras Promoç Saúde. 2007; 20(4):213-20.

30. Sant'ana JMB; Pepe VLE; Castro CGSO, Ventura M. Essential drugs and pharmaceutical care: reflection on the access to drugs through lawsuits in Brazil. Rev Panam Salud Pública. 2011; 29(2):138-44. 